\title{
Design of logical devices that perform guard interlocking and locking function
}

\author{
MAREK DŹWIAREK*
}

Dr hab. inż. Marek Dźwiarek prof. CIOP-PIB, madzw@ciop.pl, https://orcid.org/0000-0001-5817-9515 - Centralny Instytut Ochrony Pracy - Państwowy Instytut Badawczy, Warszawa, Polska

Machine guards are commonly used safety measures. The aim of the research was to determine the possibilities and limitations in the application of logic circuits providing interlocking and locking safety functions associated with guards. Particular attention was paid to the prevention of the defeating of guards. In further works it is planned to develop a methodology for the selection and design of those devices.

KEYWORDS: environmental engineering, mining, energy, safety of machinery, guards, locking, interlocking

\section{Introduction}

Work on automated machines/lines relies on the supervision of the production process and intervention in the event of irregularities. Usually, the reason for intervention is stopping the process due to jams or faulty operation of technological sensors.

Interventions require quick and frequent access to danger zones. For this reason, safety measures based on control methods and limiting access to hazardous areas are widely used in reducing the risk of accidents. The most common safety measures limiting access to danger zones in machines are guards, including movable guards, equipped with locking or interlockig devices.

\section{Research methodology}

General objective underlying the undertaking of research work was to determine the possibilities and restrictions of using logic circuits ensuring the implementation of the safety function of interlocking and locking at movable guards, allowing to reduce the risk associated with the use of machinery. Achieving this goal required:

- analysis of available system solutions that provide safety functions of interlocking and locking with movable guards,

- developing requirements for these systems based on the essential requirements and European standards,

- development of conformity assessment methodology,

- developing a methodology for the selection and design of interlocking and locking devices.

\section{Classification of shield locking devices}

According to the standard [1], the locking device (figs. 1-2) is to prevent the implementation of the hazardous functions of the machine until the guard is closed. The logic circuit performing the lock function should ensure that:

- hazardous functions cannot be performed until the guard is closed (start lock function),

- opening the guard when the machine performs hazardous functions causes a stop command (stop function related to safety),

- hazardous functions can be performed while the guard is closed; just closing the guard does not start the hazardous machine functions (restart interlocking function).

Locking devices can be divided into four types (table). 
TABLE. Classification of locking devices

\begin{tabular}{|c|c|c|c|c|}
\hline \multicolumn{2}{|c|}{ Actuation principle examples } & \multicolumn{2}{|c|}{ Actuator examples } & Type \\
\hline \multirow{5}{*}{ Mechanical } & \multirow{5}{*}{$\begin{array}{l}\text { Physical } \\
\text { contact / force }\end{array}$} & \multirow{3}{*}{ uncoded } & Rotary cam & \multirow{3}{*}{ Type 1} \\
\hline & & & Linear cam & \\
\hline & & & Hinge & \\
\hline & & \multirow{2}{*}{ coded } & Tonque (shaped actuator) & \multirow{2}{*}{ Type 2} \\
\hline & & & Trapped-key & \\
\hline \multirow{8}{*}{ Non-contact } & inductive & \multirow{5}{*}{ uncoded } & Suitable ferric metal & \multirow{5}{*}{ Type 3} \\
\hline & magnetic & & Magnet, solenoid & \\
\hline & capacitive & & Any subject object & \\
\hline & ultrasonic & & Any subject object & \\
\hline & optical & & Any subject object & \\
\hline & magnetic & \multirow{3}{*}{ coded } & Magnet coded & \multirow{3}{*}{ Type 4} \\
\hline & RFID & & Coded RFID tag & \\
\hline & optic & & Optically coded tag & \\
\hline
\end{tabular}

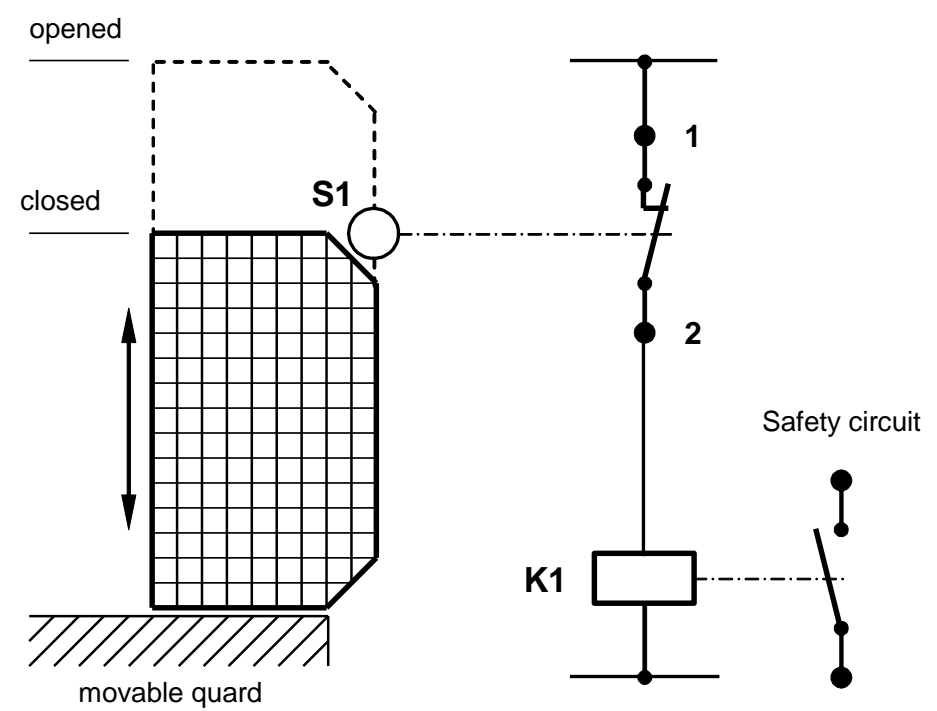

Fig. 1. Example of a logic device performing the interlocking function on the guard
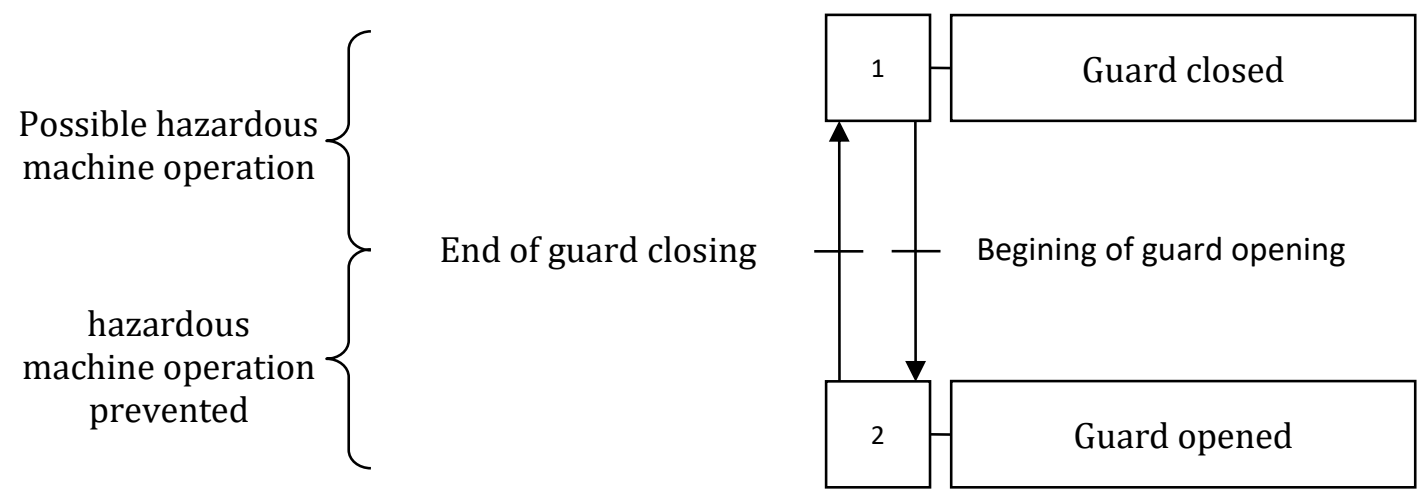

Fig. 2. Operating principle of the interlocking device

A separate group are locking devices equipped with a guard locking function (figs. 3-4) to keep it locked while the machine performs a hazardous function. The guard locking condition monitoring function monitors when the guard locking device is in the locked state and sends the corresponding output signal. 
The logic system performing the locking function should therefore perform the following safety functions:

- hazardous functions cannot be performed until the guard is closed and locked (system lock function),

- the guard remains closed and locked until the risk related to the hazardous functions (locking function) disappears,

- hazardous functions can be performed when the guard is closed and locked; mere closing and locking of the guard does not result in hazardous functions (restart interlocking function).

In practice, two types of guard locking are used: mechanical and electromagnetic locking.

Safety doors closed and locked

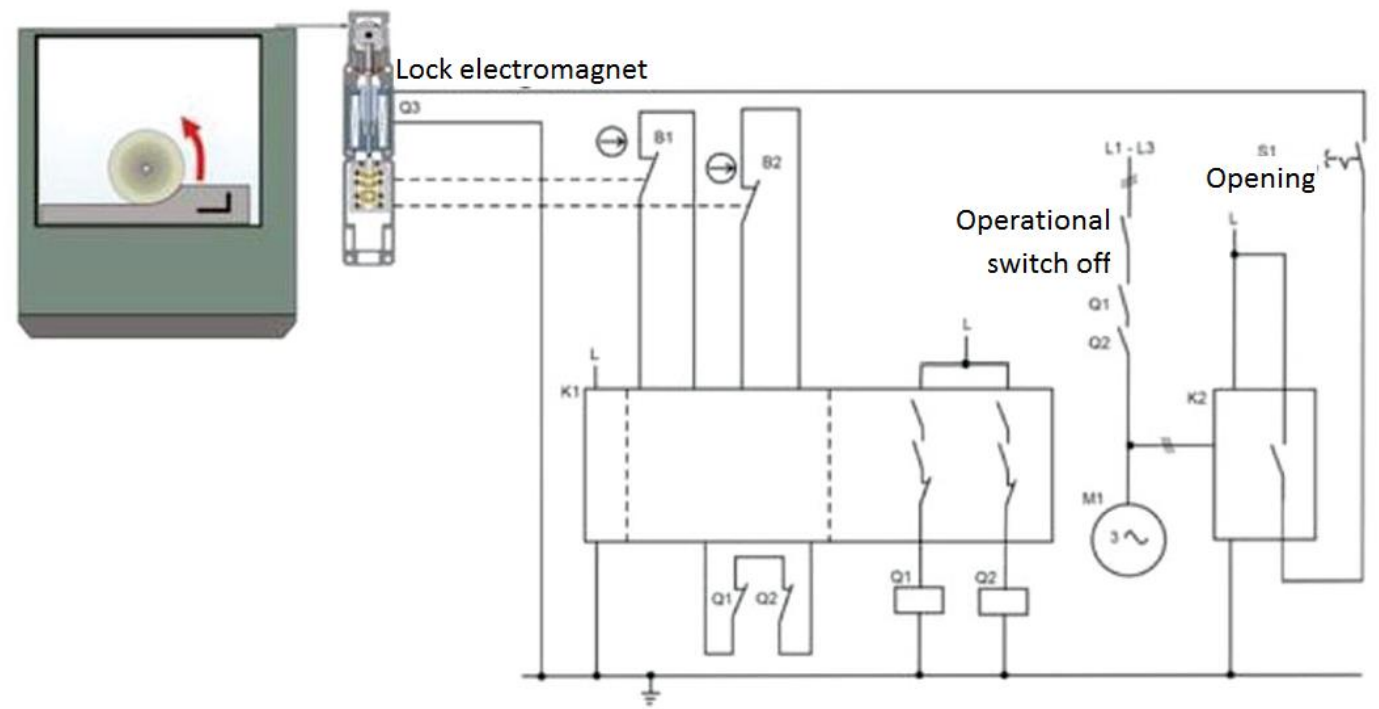

Fig. 3. Example of a logical device performing the interlocking function of the guard

\section{Safety requirements}

When formulating requirements for interlocking and locking devices for machine guards, a wide range of available solutions should be taken into account - both in terms of technology and design solutions.

\section{Design and installation requirements}

When designing the locking devices, care should be taken to ensure their effective operation. This applies to such aspects of the operation of these devices as:

- fixing efficiency of position connectors,

- minimizing the possibility of changing the location of activating elements,

- proper design of the mechanical locking device,

- adequate and monitored electromagnetic locking force,

- complementary unlocking options such as evacuation, emergency and auxiliary unlocking.

\section{Environmental requirements}

Technique and type of locking device should be suitable for the conditions of use (e.g. environment, hygiene) and intended use of the machine, including:

- temperature,

- dust,

- moisture

- vibrations and impacts,

- hygiene conditions,

- electromagnetic interactions.

\section{Control requirements}

Locking devices with or without guard locking are safety-related parts of the machine control system [2] or are subsystems or parts of subsystems related to the safety of the electric control system [3] with the task of 
preventing from hazardous situations. Therefore, defect resistance issues should be considered when designing them.

\section{User information requirements}

The locking device may be:

- designed by the machine manufacturer using separate components,

- manufactured as a complete device, ready for use.

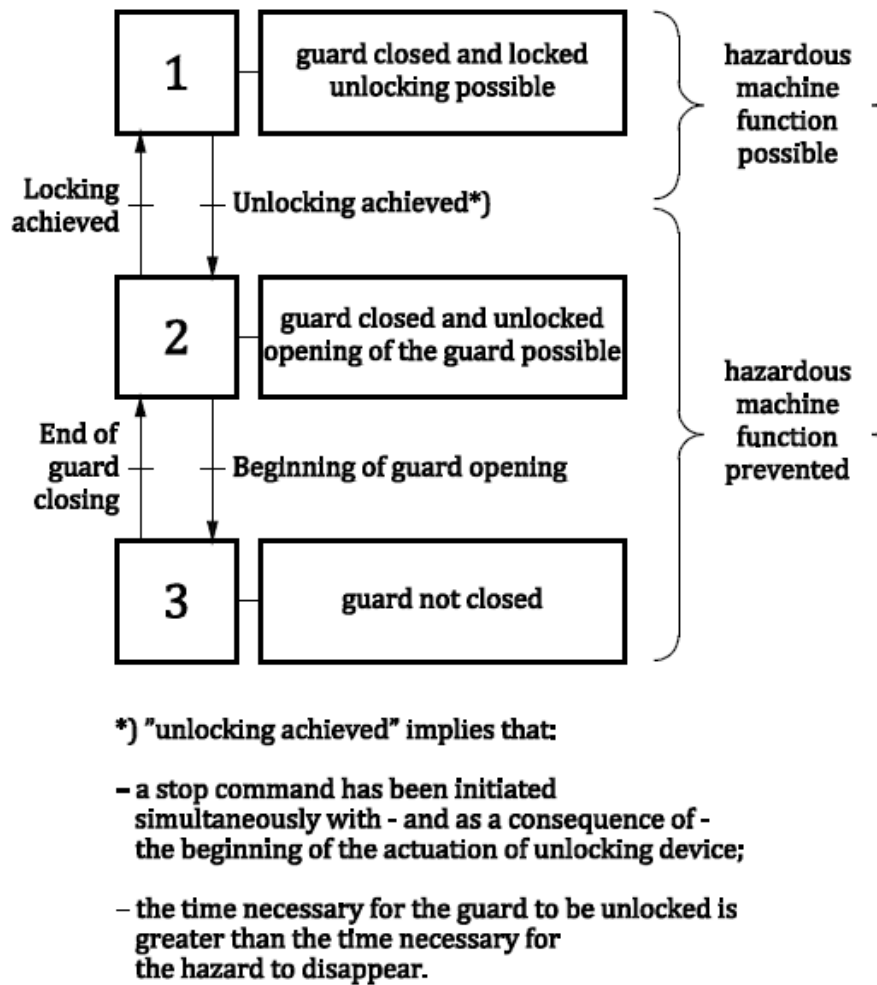

Unconditional unlocking

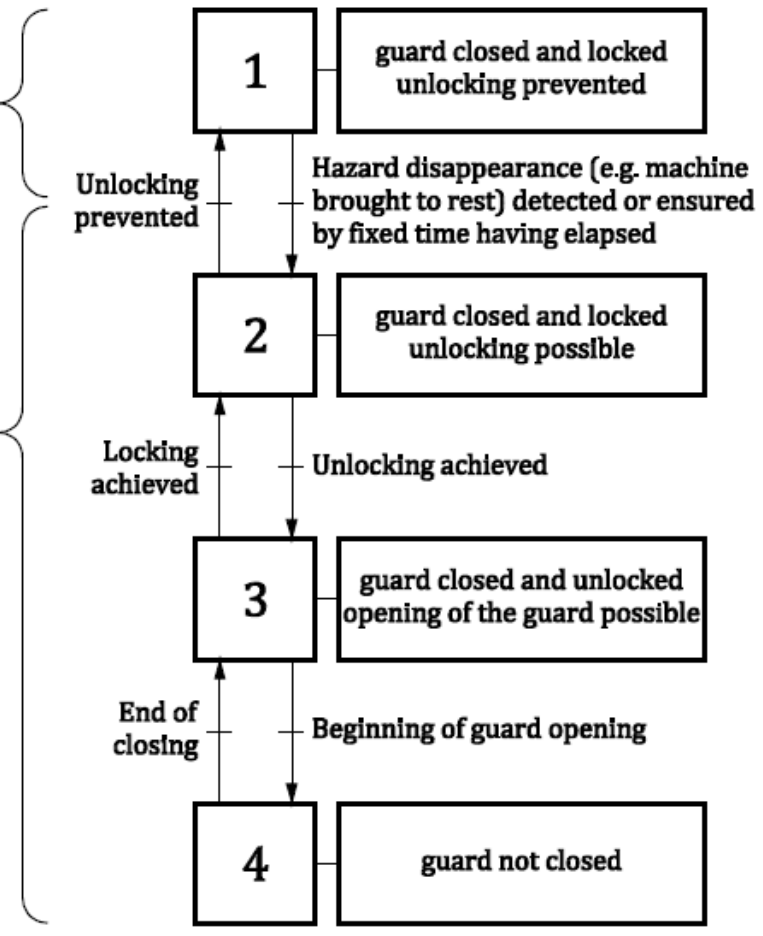

Conditional unlocking

\section{Fig. 4. Functional diagram of locking devices}

Therefore, the user information requirements that apply to the machine manufacturer or to the manufacturer of the locking devices are different. However, the marking should always be in accordance with ISO 12100: 2010, p. 6.4.

It is also important to provide the user with operating instructions containing detailed information, in particular regarding:

- device identification

- description of the intended use of the device,

- assembly, adjustment and operating instructions,

- data necessary for the user to determine PL or SIL of the intended safety functions.

\section{Defeating the guard locking devices}

An important problem associated with the use of guards is their defeating. In 2006, a report [4] was published on a German project led by BGIA and BGAG (now IFA), aimed at determining the scale and identifying the causes of this phenomenon. The analysis showed the scale of the problem $(14 \%$ of guards are permanently ignored, which accounts for $25 \%$ of machine accidents). HSE and HSL also conducted similar studies in Great Britain. The authors analyzed over 100 accident reports. According to these studies presented in [5], the main reason for $12.4 \%$ of accidents while working on machines was the defeating the safety devices. 
Also research conducted at CIOP-PIB confirmed the large scale phenomenon of defeating in Poland [6]. In surveys, the question about the risk assessment of defeating was asked to employees of OHS services and employees employed in positions equipped with guards. Respondents replied that around $15 \%$ of the guards were bypassed (9.2\% still and $4.9 \%$ occasionally). The percentage of accidents caused by defeating was estimated at $23.3 \%$, while consent to defeat the guards - at $14.6 \%$ of cases. This indicates the need to include measures to prevent defeating of protective devices and guards in the design process.

The machine should be designed to minimize motivation to defeat locking devices. Thus, the locking device should ensure as little interference as possible in activities carried out during the operation of the machine and in other phases of its life.

\section{Summary}

Devices that perform interlocking and locking functions on movable guards are currently one of the most widely used safety measures in machines. The correct application and implementation of this safety measure requires the appropriate selection of components, correct definition of the safety function, adaptation of the safety controller to the requirements associated with the implementation of the assumed functions and ensuring that the entire subsystem reaches the required SIL or PL, as well as taking into account the environmental requirements in the design process.

It is recommended that the use of interlocking and locking devices at guards should comply with the appropriate methodology, which should include the phases: selection of components, definition of control functions, design of systems and development of controller software, verification and operation tests, and finally validation and assessment of conformity with essential requirements. Further activities include development of a methodology for the selection and design of devices that perform the logical functions of interlocking and locking at movable guards. Particular attention will be paid to the extremely important issues of preventing the defeating of safety devices. Information materials on requirements, methodology of conformity assessment and methodology of selection and design of these devices will also be developed.

This paper has been based on the results of a research task carried out within the scope of the fourth stage of the National Programme "Improvement of safety and working conditions" partly supported in 2017-2019 - within the scope of state services - by the Ministry of Family, Labour and Social Policy. The Central Institute for Labour Protection - National Research Institute is the Programme's main coordinator

\section{REFERENCES}

[1] PN EN ISO 14119:2014-03. Bezpieczeństwo maszyn - Urządzenia blokujące sprzężone z osłonami Zasady projektowania i doboru. PKN.

[2] PN-EN ISO 13849-1:2016-02. Bezpieczeństwo maszyn - Elementy systemów sterowania związane z bezpieczeństwem - Część 1: Ogólne zasady projektowania. PKN.

[3] PN-EN 62061:2008. Bezpieczeństwo maszyn - Bezpieczeństwo funkcjonalne elektrycznych, elektronicznych i elektronicznych programowalnych systemów sterowania związanych z bezpieczeństwem. PKN.

[4] "Manipulation von Schutzeinrichtungen an Maschinen" - Report. HVGB (Hauptverband der gewerblichen Berufsgenossenschaften) https://publikationen.dguv.de/dguv /pdf/10002/reportgesamtmanipulation.pdf (2019). ISBN 3-88383-698-2.

[5] Hopkinson J., Lekka C. "Identifying the human factors associated with the defeating of interlocks on Computer Numerical Control (CNC) machines". Health and Safety Laboratory. RR974 Research Report (2013).

[6] Dźwiarek M. „Obchodzenie urządzeń ochronnych i osłon przy maszynach - skala zjawiska”. Bezpieczeństwo Pracy. 6 (2014): 20-24. 